\title{
EVALUATION OF EFFICIENCY IN TOURISM INDUSTRY
}

\author{
Slavica Tomic, Associate Professor ${ }^{1}$ \\ Aleksandra Marcikic Horvat, Assistant Professor $^{2}$
}

DOI: https://doi.org/10.31410/tmt.2018.289

\begin{abstract}
The main goal of this paper is to evaluate efficiency of regions tourism sector in order to improve countries competitiveness on global market. Efficiency is observed as relation of multiple outputs (international tourist arrivals, international tourism inbound receipts and tourism industry GDP) and inputs (government expenditure and prioritization of tourism) for four-year period. Results show that Croatia and Montenegro achieve maximal efficiency, compared to the other countries in this region.
\end{abstract}

Keywords: Efficiency Analysis, Tourism, Data Envelopment Analysis

\section{INTRODUCTION}

$\mathrm{T}$

lourism industry has recorded significant growth and has an impressive influence on the world economy. International tourist arrivals were increasing in the past seven decades, from 25 million in 1950s to 1,326 million in 2017. According to the UNWTO Tourism Highlights 2018 [1] international tourist arrivals increased by $7.0 \%$ in 2017 which was the highest grow since the 2009 global economic crisis and were recorded, with 86 million more than in 2016. International tourism receipts also increased by $4.9 \%$ and achieved US\$ 1,340 billion in 2017. International tourism generated another US\$ 240 billion from international passenger transport services and therefore total exports from international tourism reached US\$ 1.6 billion in revenue. In the context of a worldwide export category, tourism is the world's third largest export sector after chemicals and fuels and ahead of automotive and food products. So, we can say that tourism sector is a significant driver in economic development, that contribute with over $10 \%$ to global GDP and account for 1 in 10 jobs on the planet. Therefore, tourism industry today has a very important role and influence on country's competitiveness on global market. Tourism became a significant driver of development providing unique opportunities for many countries. Thus, relationship between tourism and economic growth takes the attention of many authors [2] - [6]. International tourism is expected to be a major vehicle of economic development in industrializing countries in the twenty-first century.

If tourism sector can be regarded as a business entity, it is possible assume that the given branch should effectively manage its resources. The efficient use of the available material, financial and human resources should generate increase in outcomes in the form of a larger the number of tourist arrivals and nights, the participation of the tourism sector in the increase of gross domestic product, the increase in employment in tourism industry, the degree of tourist satisfaction, etc. In other words, if a country is not able to make maximum results from available resources, it is considered ineffective in the tourism sphere, thus it will attract a relatively small number of tourists. The reasons for the inefficiency of tourism may be the excessive volume of resources used, their inadequate combination or imbalance in resources and outcomes. In particular, the efficiency of tourism can be influenced by state regulation as a limiting factor in the utilization of tourist ca-

University of Novi Sad, Faculty of Economics Subotica, Segedinski put 9-11, 24000 Subotica, Serbia University of Novi Sad, Faculty of Economics Subotica, Segedinski put 9-11, 24000 Subotica, Serbia 
pacities, global trends in environmental protection, demographic changes and terrorism, as well as social and cultural aspects that can limit the operation of tourism activity. Thus, the tourist destination can achieve a competitive advantage by optimizing the use of destination resources with the aim of their transformation into attractions. A comparative advantage implies resources available to the destination (human resources, natural resources, knowledge, capital, infrastructure - tourism infrastructure, cultural and historical resources), but a competitive advantage relates to the ability of a destination to use these resources effectively and in the long-term [7].

The main aim of increasing the competitiveness of the tourist destination is tourist satisfaction. According to Dwyer and Kim [8], each destination in order to enhance its competitive advantage should ensure that its overall, ,attractiveness" and the tourist experience it offers should be superior to alternative destinations. This is connected with the efforts of the tourism offer (input) to satisfy the expectations of tourists which will result in higher output (tourist arrivals, tourism receipts). Author Hassan [9] points out that the destination will be competitive if its market share, measured by the number of visitors and revenue generated, is growing.

In literature we can find several models for measuring tourism competitiveness. The main goal of the paper is to evaluate efficiency of regions tourism sector in order to improve countries competitiveness on global market. The countries included in this analysis are: Bosnia and Herzegovina, Montenegro, Croatia, Republic of Macedonia, Slovenia and Serbia. Efficiency is observed as relation of multiple outputs and inputs using Data Envelopment Analysis (DEA). The output-oriented DEA model with a constant return to scale has been applied separately for every year. Relative efficiency of observed countries has been calculated as relation of three output variables (international tourist arrivals, international tourism inbound receipts tourism industry GDP) and two input variables (government expenditure and prioritization of tourism). In this paper authors used data from Travel \& Tourism Competitiveness Report [10] - [12] which measures the factors and policies that make it attractive to develop tourism sector in different countries. Through analysis of each pillar and sub pillar, businesses and governments can better understand the particular challenges to the sector's growth and after analysis they can formulate appropriate policies and actions.

The chapter two focuses on previous studies that highly motivated us for this work. Chapter three describes the applied methodology. The model formulation and the results are presented in the fourth chapter. The last chapter contains the main conclusions and guidelines for future research.

\section{LITERATURE REVIEW}

This paper intends to enrich tourism literature, pointing to a specific aspect of the observation of tourist units. Namely, most of the literature that considers the efficiency of tourism considers as statistical units hotels, restaurants and other types of catering facilities. On the contrary, the presented work will shift the focus of the analysis to geographical areas, more precisely to countries as statistical units. The previous work [13] also analyzes the efficiency of tourism development of this region, but using another DEA model and different output and input variables. Also, they only observe efficiency for one time period, while the goal of our current study is to follow the changes in the relative efficiency over a longer period of time, in order to perceive the existence of potential global trends and changes. 
Authors Ilic and Petrevska [14] in the recent study applied Data Envelopment Analysis to determine tourism efficiency of Serbia and the surrounding countries. Tourism expenses and the number of beds are used as inputs, while the number of arrivals, the number of nights spent and tourism revenue in 2016 are used as output parameters. The applied analysis has shown that in the aspect of tourism 6 countries are relatively efficient, while other 9 are relatively inefficient. The efficient countries are: Montenegro, Bosnia and Herzegovina, Croatia, Greece, Austria and Albania, while Serbia, FYR Macedonia, Slovenia, Romania, Bulgaria, Italy, Hungary, Slovakia and the Czech Republic. In order to improve their efficiency, the inefficient countries should reduce tourism costs and the number of beds, and increase some of the output parameters. This paper should give the instructions to inefficient countries how to improve their efficiency.

Measuring tourism efficiency is a topic of great interest among researchers [15]. They use some input output variables to measure and to improve a country or region's tourism efficiency. Authors [16] in their paper examined the economic efficiency of tourism in Romania and they conclude that measuring the efficiency of tourism should contribute to the improvement of the competitive position of the country.

On the level of the regions of individual countries, several efficiency researches were carried out using the Data Envelopment Analysis [17]. Group of authors [18] have examined the tourist competitiveness of regions in Italy and how this degree of competitiveness has changed over years. In another paper, [19] authors examine the effectiveness of France's tourist destinations. Focusing on the evaluation of the efficiency of tourism as an economic branch in the Republic of China, [20] this study made a comparation of city administrations, provinces and autonomous regions in China. Their results indicate a serious imbalance in the development of tourism in some regions and suggest the necessary advancement for these regions. Another interesting study [21] focuses on determining whether UNESCO nominations determine the flow of tourist trips in Italian regions. It is also interesting to mention the study [22] whose goal was to create a unique index of competitiveness of tourism. The survey carried out the ranking of 139 countries using the DEA method.

Toma [23] applied DEA model to evaluate the efficiency of tourism sector at regional level, in order to offer additional information and indicate necessary decision making to reach an optimal size of tourism market. The results of this survey indicate the insufficient efficiency of the regions that have a higher number of tourist visits and accentuate the need for intervention regarding the allocation of scarce resources (labor, capital, infrastructure) or implementation of real measures to increase demand and outcomes.

Competition is now widely accepted as one of the most important factors determining the success of organizations, industry, regions and countries in the long run. Competitiveness in tourism can be primarily considered from the aspect of the competitiveness of the tourist destination. Intensified competition and limited resources have become key factors for the success of tourism destinations [24]. The tourism sector can be described as competitive only when tourist destinations are attractive and their tourist product has superior value. Destinations are considered competitive as long as they are well positioned on the market in relation to their competitors [9], [24]. This is an approach that focuses on ,price differences” [8], „tourism consumption” [26], ,attraction of visitors” [7], or ,economic progress” [3]. The authors [7] and [27] point out that, in addition to the economic dimension of competitiveness, environmental, social, cultural, political and technological aspects should be considered. So, competitiveness in the tourist industry is multi-dimensional and complex. Some authors correlate the competitiveness of destinations with the well-being of the local population, with socioeconomic prosperity and 
(or) improving the quality of life of the population [28] - [30], [7], [8]. According to [31] and [32] increasing the quality of life of the local population has an impact on the competitiveness of the destination through hospitality, which refers to kindness, friendship shown to tourists, as well as through education and skills that influence the establishment of good relations with tourists.

\section{METHODOLOGY}

Data Envelopment Analysis (DEA) is a mathematical programming technique used to analyze and compare the efficiency of different entities. Unlike parametric statistical methods, DEA compares the efficiency of each individual entity with the highest achieved level of efficiency, rather than the average. It is a non-parametric approach because it does not require a priori assumption about the analytical form of the observed inputs and outputs. An important advantage of the DEA method is that the input and output variables can be presented by different types of metrics. The results of DEA present the relative efficiency measures, as they depend on the number of entities involved in the analysis, as well as the number and structure of the input and output. Based on the results of the analysis, it can be determined how many decision-making units (DMUs) are ineffective in relation to those effective, and how much it takes to reduce a certain input and / or increase a particular output in order to make these units effective. The number of DMUs which are included in the analysis depends on the goal of the study, as well as the number of homogeneous units whose effect in practice has to be compared.

There are different formulations of the linear programming models used in the DEA analysis. In this study, the output-oriented DEA model with a constant return to scale is will be applied to evaluate efficiency of tourism in our region. This model was first introduced in 1978 by Charnes Cooper and Rhodes and the analysis are carried out by solving the following model [33] of linear programming for each entity, separately for every year:

$$
\begin{aligned}
& \max \Phi_{k}+\varepsilon \sum_{r=1}^{s} s_{r}+\varepsilon \sum_{i=1}^{m} s_{i} \\
& \Phi_{k} y_{r k}-\sum_{j=1}^{n} y_{r j} \lambda j+s_{r}=0 \quad r=1 \ldots s \\
& x_{i k}-\sum_{r=1}^{n} x_{i j} \lambda j-s_{i}=0, \quad i=1 \ldots m \\
& \lambda j, s_{r}, s_{i} \geq 0, j=1 \ldots n
\end{aligned}
$$

where $s$ are outputs and $m$ inputs, $y_{r k}$ is the amount of output $r$ used by DMU $k, x_{i k}$ is the amount of input $I$ used by DMU $k$ and $s_{r}$ are $s_{i}$ the output and input slacks, respectively. Efficiency of DMU $k$ is $\Phi_{k}$.

\section{FORMULATION AND RESULTS OF DEA MODEL}

The aim of this paper is to examine the efficiency the tourism sector in different countries of our region. The Data Envelopment Analysis is a convenient method for comparing the efficiency of tourism industry, due to the different nature, number and measuring units of inputs and outputs. The data are collected from the report of the World Economic Forum - The Travel \& Tourism Competitiveness Report [10] - [12]. These reports were published in 2013, 2015 and 2017 and 
present a detailed analysis of the competitiveness and improvement of the tourism sector for more than 130 countries across the world. In the analysis we will use data from the following countries in our region: Bosnia and Herzegovina, Montenegro, Croatia, Republic of Macedonia, Slovenia and Serbia. The report from 2015 does not contain data for Bosnia and Herzegovina, so we will exclude this country from the analysis for this particular year.

In order to analyze the efficiency of tourism industry, it is necessary to analyze the relation of selected inputs and outputs. In our research, the inputs will be presented through the following two variables: government prioritization of travel and tourism industry and travel and tourism government expenditure. The first variable represents how high of a priority is the development of the travel \& tourism (T\&T) industry for the government of a country $(1=$ not a priority at all, $7=$ a top priority). This next input variable includes expenditures (transfers or subsidies) made by government agencies to provide T\&T services such as cultural (e.g. museums), recreational (e.g. national parks), clearance (e.g. immigration, customs) and so on to visitors [10] - [12].

Following three variables represent the outputs of the DEA model: international tourist arrivals, international tourism inbound receipts and travel and tourism industry GDP. International tourism receipts are expenditures by international inbound visitors, including payments to national carriers for international transport. These receipts include any other prepayment made for goods or services received in the destination country [10] - [12]. The Data Envelopment Analysis has been performed for every year separately, using the data from the abovementioned reports. The input and output data from the latest report are presented in the next tables.

\begin{tabular}{|l|c|c|}
\hline \multicolumn{1}{|c|}{ Country } & $\begin{array}{c}\text { Government prioritization of } \\
\text { travel and tourism industry }\end{array}$ & $\begin{array}{c}\text { T\&T government expenditure } \\
\text { (\% government budget) }\end{array}$ \\
\hline Bosnia and Herzegovina & 3,3 & 1,1 \\
\hline Croatia & 5,2 & 1,3 \\
\hline FYR Macedonia & 5 & 1,3 \\
\hline Montenegro & 5,8 & 2,6 \\
\hline Serbia & 3,7 & 0,5 \\
\hline Slovenia & 4,3 & 4,2 \\
\hline
\end{tabular}

Table 1: Input variables of DEA model for 2017 year

\begin{tabular}{|l|c|c|c|}
\hline \multicolumn{1}{|c|}{ Country } & $\begin{array}{c}\text { International } \\
\text { tourist arrivals }\end{array}$ & $\begin{array}{c}\text { International tourism } \\
\text { inbound receipts } \\
\text { (US \$ millions) }\end{array}$ & $\begin{array}{c}\text { T\&T industry GDP } \\
\text { (\% of total) }\end{array}$ \\
\hline Bosnia and Herzegovina & 678271 & 660,7 & 2,7 \\
\hline Croatia & 12683179 & 8833,3 & 10,1 \\
\hline FYR Macedonia & 48553 & 266,8 & 1,5 \\
\hline Montenegro & 1559924 & 902 & 11,3 \\
\hline Serbia & 1132221 & 1048,4 & 2,2 \\
\hline Slovenia & 2706781 & 2504,4 & 3,6 \\
\hline
\end{tabular}

Table 2: Output variables of DEA model for 2017 year

The Open Source DEA software has been used to perform the analysis. In this case, the country is observed as one entity and its relative efficiency in relation to input and output is examined by solving a linear programming model (1) for every country. The Data Envelopment Analysis has been performed separately for every year and the results of output - oriented CCR DEA model with constant return on scale are presented in the next tables. 


\begin{tabular}{|l|c|c|c|}
\hline \multicolumn{1}{|c|}{ Country/Year } & $\mathbf{2 0 1 3}$ & $\mathbf{2 0 1 5}$ & $\mathbf{2 0 1 7}$ \\
\hline Bosnia and Herzegovina & 0,27 & - & 0,42 \\
\hline Croatia & 1,00 & 1,00 & 1,00 \\
\hline FYR Macedonia & 0,15 & 0,11 & 0,15 \\
\hline Montenegro & 0,74 & 0,80 & 1,00 \\
\hline Serbia & 0,26 & 0,41 & 0,57 \\
\hline Slovenia & 0,39 & 0,40 & 0,43 \\
\hline
\end{tabular}

Table 3: Efficiency scores of DEA models

Based on the results of the DEA analysis for 2017 year, we can conclude that Montenegro and Croatia obtain the highest relative efficiency of tourism industry in our region (in terms of the best relationship of the observed outputs and inputs). These countries achieve relative efficiency of 1, which means they have the optimal ratio of observed outputs and inputs. Slovenia, Serbia, Bosnia and Herzegovina and FYR of Macedonia are below the efficiency limit because their relative efficiency is less than 1 . For these countries, a more detailed analysis of the results of the DEA model is needed in order to identify the causes of inefficiency and formulate proposals for improving output/input relations.

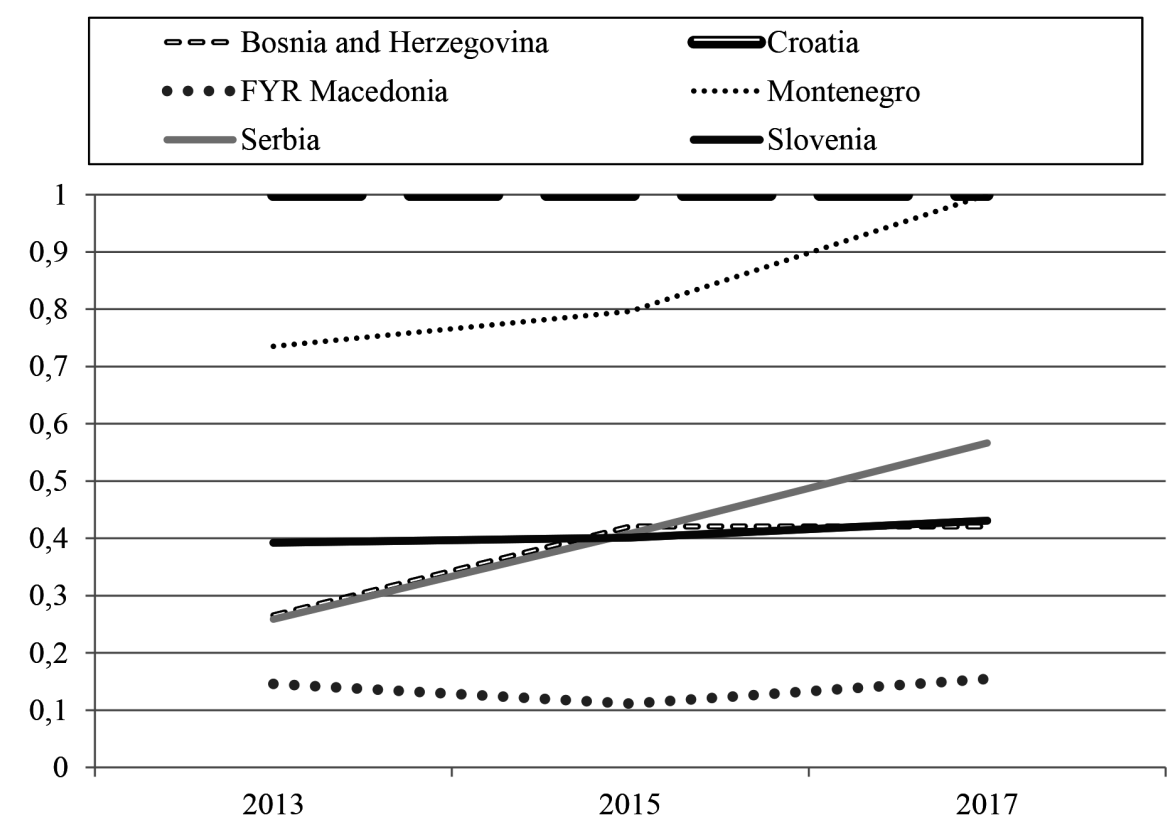

Figure 1: Changes in relative efficiency scores

The figure 1 shows the changes in relative efficiency scores from 2013 until 2017. We can see that all observed countries have increased their relative efficiency in this period, except Croatia which obtains the maximal efficiency score for the whole time. Montenegro systematically improved the relation of outputs and inputs and from the efficiency of 0,74 in 2013 obtained the maximal efficiency in 2017. After Montenegro, Serbia also significantly improved their position from quite low efficiency score of 0,26 in 2013 to 0,57 in 2017, but further actions are needed to attain the higher efficiency score in the future. Slovenian increase of efficiency is very slow and its score is constantly around 0,4. Bosnia and Herzegovina also managed to improve efficiency from 0,27 to 0,42 in the observed period, while the FYR of Macedonia has the most inefficient tourism industry with relative efficiency score below 0,2 . 
Data Efficiency Analysis is a very powerful method because it also provides information on how relative efficiency can be improved for inefficient entities. Therefore, the next tables present the peer groups for our inefficient countries and the corresponding values of lambda for 2017 year. Peer group represent the set of efficient units from which an inefficient unit's inefficiency has been determined. From the following tables, we can conclude that Serbia should look up to Croatian way of efficient allocation of observed outputs and inputs. All other inefficient countries (Slovenia, Bosnia and Herzegovina and FYR of Macedonia) should follow the experiences of both Croatia and Montenegro to improve their relative efficiency position.

\begin{tabular}{|l|c|}
\hline \multicolumn{1}{|c|}{ Country } & Peer Group \\
\hline Bosnia and Herzegovina & Croatia, Montenegro. \\
Croatia & Croatia. \\
FYR Macedonia & Croatia, Montenegro. \\
Montenegro & Montenegro. \\
Serbia & Croatia. \\
Slovenia & Croatia, Montenegro. \\
\hline
\end{tabular}

Table 4: Peer Groups for inefficient countries in 2017 year

\begin{tabular}{|l|c|c|}
\hline \multicolumn{1}{|c|}{ Country } & Croatia & Montenegro \\
\hline Bosnia and Herzegovina & 0,37 & 0,24 \\
\hline Croatia & 1,00 & 0,00 \\
\hline FYR Macedonia & 0,91 & 0,04 \\
\hline Montenegro & 0,00 & 1,00 \\
\hline Serbia & 0,38 & 0,00 \\
\hline Slovenia & 0,64 & 0,17 \\
\hline
\end{tabular}

Table 5: Lambda values of DEA model for 2017 year

The table 6 shows the projections of input and output variables used in the DEA model. Those projections actually represent the guidelines to decision makers on how to improve the efficiency of tourism sector. The results show that Bosnia and Herzegovina, FYR of Macedonia, Serbia and Slovenia should gain higher level of all output variables used in the DEA model. The projections also show that Slovenia could even decrease its travel and tourism expenditure (for $1,27 \%$ ) to gain this level of outputs.

\begin{tabular}{|l|c|c|c|c|c|}
\hline \multicolumn{1}{|c|}{ Country } & $\begin{array}{c}\text { International } \\
\text { tourist arrivals }\end{array}$ & $\begin{array}{c}\text { International } \\
\text { tourism } \\
\text { inbound } \\
\text { receipts }\end{array}$ & $\begin{array}{c}\text { T\&T } \\
\text { industry GDP }\end{array}$ & $\begin{array}{c}\text { Government } \\
\text { prioritization } \\
\text { of travel } \\
\text { and tourism } \\
\text { industry }\end{array}$ & $\begin{array}{c}\text { T\&T } \\
\text { government } \\
\text { expenditure }\end{array}$ \\
\hline $\begin{array}{l}\text { Bosnia and } \\
\text { Herzegovina }\end{array}$ & 5039077,78 & 3465,40 & 6,42 & 3,30 & 1,10 \\
\hline Croatia & 12683179,00 & 8833,30 & 10,10 & 5,20 & 1,30 \\
\hline $\begin{array}{l}\text { FYR } \\
\text { Macedonia }\end{array}$ & 11648116,65 & 8104,40 & 9,71 & 5,00 & 1,30 \\
\hline Montenegro & 1559924,00 & 902,00 & 11,30 & 5,80 & 2,60 \\
\hline Serbia & 4878145,77 & 3397,42 & 3,88 & 2,00 & 0,50 \\
\hline Slovenia & 8392281,86 & 5814,16 & 8,36 & 4,30 & 1,27 \\
\hline
\end{tabular}

Table 6: Projections of DEA model for 2017 year 
Solution of DEA model also provides information on slacks. Slacks represent the potential improvements in input and output variables for the inefficient units in the data set when compared with their peer efficient targets. The slacks relate to the further increases in output or reduction in input that could be gained beyond that implied by the radial projection.

\begin{tabular}{|l|c|c|c|c|c|}
\hline \multicolumn{1}{|c|}{ Country } & $\begin{array}{c}\text { International } \\
\text { tourist arrivals }\end{array}$ & $\begin{array}{c}\text { International } \\
\text { tourism } \\
\text { inbound } \\
\text { receipts }\end{array}$ & industry GDP & $\begin{array}{c}\text { Government } \\
\text { prioritization } \\
\text { of travel } \\
\text { and tourism } \\
\text { industry }\end{array}$ & $\begin{array}{c}\text { T\&T } \\
\text { government } \\
\text { expenditure }\end{array}$ \\
\hline $\begin{array}{l}\text { Bosnia and } \\
\text { Herzegovina }\end{array}$ & 3426829,38 & 1894,92 & 0,00 & 0,00 & 0,00 \\
\hline Croatia & 0,00 & 0,00 & 0,00 & 0,00 & 0,00 \\
\hline $\begin{array}{l}\text { FYR } \\
\text { Macedonia }\end{array}$ & 11333718,39 & 6376,78 & 0,00 & 0,00 & 0,00 \\
\hline Montenegro & 0,00 & 0,00 & 0,00 & 0,00 & 0,00 \\
\hline Serbia & 2878944,35 & 1546,23 & 0,00 & 1,70 & 0,00 \\
\hline Slovenia & 2108274,23 & 0,00 & 0,00 & 0,00 & 2,93 \\
\hline
\end{tabular}

Table 6: Slacks of DEA model for 2017 year

\section{CONCLUSIONS}

In a period characterized by global economic instability and constant changes in the economic environment, the development of tourism is an issue of exceptional importance, due to direct and indirect contributions to the development of both individual countries and the regions. The direct impact of tourism development is reflected for example in the increase of national income, while the indirect effects are manifested in connecting countries and developing critical infrastructure to improve the competitiveness of the observed country. In current conditions, when unemployment is one of the biggest problems in the world, and especially in our environment, the promotion of tourism development can play a very important role in creating new jobs. In the past decades travel \& tourism and its enabling ecosystem have proven to be significant drivers of economic growth, contributing over $10 \%$ to global GDP and accounting for 1 in 10 jobs on the planet [10].

For these reasons, the analysis of the efficiency of tourism industry is an extremely attractive topic. The results of applied Data Envelopment Analysis showed that in our region Montenegro and Croatia use their resources in the most efficient way. On the other hand, Bosnia and Herzegovina, FYR of Macedonia, Serbia and Slovenia, with a high level of inputs, do not realize the maximal level of outputs, and for this reason they do not achieve maximum efficiency. As our research is one of the first to deal with the analysis of the efficiency of tourism development at the macroeconomic level, it would be interesting in the future to compare the results of our region with other regions in the world. It would also be attractive to analyze the efficiency of individual regions within countries and to set guidelines for future investments that would bring the greatest efficiency of the development of this sector. 


\section{REFERENCES}

[1] UNWTO Tourism Highlights 2018 Edition

https://www.e-unwto.org/doi/pdf/10.18111/9789284419876 (13.11.2018.)

[2] Sokhanvar, A., Ciftcioglu S., Javid, E. (2018) Another look at tourism- economic development nexus, Tourism Management Perspectives, Vol. 26, pp. 97-106.

[3] Li, C. C., Mahmood, R., Abdullah, H., Chuan, O. S. (2013) Economic growth, tourism and selected macroeconomic variables: A triangular causal relationship in Malaysia, The Journal of Applied Economic Research, Vol. 7 (2), pp. 185-220.

[4] Corrie, K., Stoeckl, N., Chaiechi, T. (2013) Tourism and economic growth in Australia: An empirical investigation of causal links, Tourism Economics, Vol. 19 (6), pp. 1317-1344

[5] Dritsakis, N. (2012) Tourism development and economic growth in seven Mediterranean countries: A panel data approach, Tourism Economics, Vol. 18 (4), pp. 801-816.

[6] Zortuk, M. (2009) Economic impact of tourism on Turkey's economy: Evidence from cointegration tests, International Research Journal of Finance and Economics, Vol. 25, pp.231-239.

[7] Ritchie, J.R.B., Crouch, G.I. (2003) The Competitive Destination. A Sustainable Tourism Perspective. CABI Publishing, UK.

[8] Dwyer, L., Kim, C. (2003) Destination Competitiveness: Determinants and Indicators, Current Issues in Tourism, Vol. 6 (5), pp. 369-414.

[9] Hassan, S. S. (2000) Determinants of Market Competitiveness in an Environmentally Sustainable Tourism Industry, Journal of Travel Research, Vol. 38 (3), pp. 239-245.

[10] http://reports.weforum.org/travel-and-tourism-competitiveness-report-2017/ (10.11.2018)

[11] http://reports.weforum.org/travel-and-tourism-competitiveness-report-2015/ (10.11.2018)

[12] http://reports.weforum.org/travel-and-tourism-competitiveness-report-2013/ (10.11.2018)

[13] Marcikic Horvat A., Radovanov B. (2016) Analiza efikasnosti razvoja turizma regiona primenom DEA metode, International Thematic Monograph - Thematic Proceedings: Modern Management Tools and Economy of Tourism Sector in Present Era, pp. 115-127.

[14] Ilić, I., Petrevska, I. (2018) Using DEA method for determining tourism efficiency of Serbia and the surrounding countries, Hotel and Tourism Management, Vol. 6 (1), pp. 73-80.

[15] Li, G., Song, H., Cao, Z., Wu, D.C. (2013) How competitive is Hong Kong against its competitors, An econometric study. Tourism Management. Vol. 36, pp. 247-256.

[16] Onet, A., N., Predonu A., M. (2013) Economic and Social Efficiency of Tourism, Procedia - Social and Behavioral Sciences, Vol. 92 (10), pp. 648-651

[17] Fuchs, M. (2004) Strategy development in tourism destinations: a DEA approach, The Poznań University of Economics Review, Vol. 4 (1), pp. 52-73

[18] Cracolici, M.F., Nijkamp, P., Cuffaro, M. (2007) Efficiency and Productivity of Italian Tourist Destinations: A Quantitative Estimation Based on Data Envelopment Analysis and the Malmquist Method, U Matias A., Nijkamp P., Neto P., Advances in Modern Tourism Research, Physica-Verlag, Heidelberg, pp. 325-343.

[19] Botti, L., Peypoch, N., Robinot, E., Solonandrasana, B. (2009) Tourism destination competitiveness: the French regions case, European Journal of Tourism Research, Vol. 21, pp. 5-24.

[20] Bi, G., Luo, Y., Liang, L. (2011) Efficiency Evaluation of Tourism Industry with Data Envelopment Analysis (DEA): A Case Study in China, Journal of China Tourism Research, Vol. 7(1), pp. 104-116.

[21] Cuccia, T., Guccio, C., Rizzo, I. (2013) Does UNESCO inscription affect the performance of tourism destinations? A regional perspective, ACEI working paper series, AWP-042013.

[22] Martín, J.C., Mendoza, C., Román, C. (2015) A DEA Travel-Tourism Competitiveness Index, Social Indicators Research, pp. 1-21. 
[23] Toma, E. (2014) Regional Scale Efficiency Evaluation by Input-oriented Data Envelopment Analysis of Tourism Sector, International Journal of Academic Research in Environment and Geography, Vol. 1 (1), pp. 15-20.

[24] Novais, M., A., Ruhanen, L., Arcodia C. (2018) Destination competitiveness: A phenomenographic study, Tourism Management, Vol. 64, pp. 324-334

[25] Hong, W. (2009) Global competitiveness measurement for the tourism sector, Current Issues Tourism, Vol. 12 (2), pp. 105-132.

[26] Crouch,G.I., Ritchie,J.B. (2012) Destination competitiveness and its implications for host community $Q O L$, In Handbook of tourism and quality-of-life research, Springer, pp. 491513.

[27] Craigwell, R., (2007) Tourism Competitiveness in Small Island Developing States, Research Paper 19, UNU-WIDER, United Nations University (UNU), pp. 1-26.

[28] Bahar, O., Kozak, M. (2007) Advancing Destination Competitiveness Research: Comparison Between Tourists and Service Providers, Journal of Travel \& Tourism Marketing, Vol. 22 (2), pp. 61-71.

[29] Buhalis, D. (2001) Tourism in Greece: Strategic Analysis and Challenges, Current Issues in Tourism, Vol. 4 (5), pp. 440-480.

[30] Crouch, G.I., Ritchie, J.R.B. (1999) Tourism, Competitiveness, and Societal Prosperity, Journal of Business Research, Vol. 44, pp. 137-152.

[31] Andereck, K.L., Nyaupane, G.P. (2011) Exploring the nature of tourism and quality of life perceptions among residents, Journal of Travel Research, Vol. 50 (3), pp. 248-260.

[32] Ridderstaat, J., Croes, R., Nijkamp, P. (2016) The tourism development-quality of life nexus in a small island destination, Journal of Travel Research, Vol. 55 (1), pp. 79-94.

[33] A. Charnes, W. W. Cooper and E. Rhodes, "Measuring the efficiency of decision-making units", European Journal of Operational Research, vol. 2, no. 6, pp. 429-444, 1978. 